\title{
A DICHOTOMY IN THE DIACHRONIC STRUCTURE OF FAMILY NAMES
}

\author{
WiLly VAN LANGENDONCK \\ Katholieke Universiteit Leuven, Belgium
}

\begin{abstract}
Usually, four categories of family names are distinguished: patronymics, names of origin, occupational names, and bynames in a very large sense. Here, there is a problem. This looks like the wastebasket! The idea of bynames, in a large sense, does not indicate a motivational category. Instead, I will propose a dichotomy, namely a major division into "relational" and "characterizing" names.

In relational names, there is a relation between the name bearer and an entity outside of that person, for instance, a family or another entity outside of this person, a place or time. This concept of relation essentially applies to the meaning of the genitive in a broad sense, namely origin, human or geographical, where two entities are related, e.g., Robin-s, -son.

On the other hand, we have characterization, which refers to one and the same person, where some or other property of the name bearer is named, e.g., names such as Smith, Brown, etc. Here, a continuum can be set up.
\end{abstract}

Keywords: anthroponymy, dichotomy, relational, characterization.

\section{Introduction}

In this paper, I would like to propose a dichotomy in the diachronic semantic and formal structure of family names.

The extensive book by Silvio and Andrea Brendler on European personal names in seventy-seven languages shows that, by and large, in all of Europe, the same system is used.

As a rule, four categories are distinguished: patronymics, names of origin, occupational names, and bynames, or nicknames in a very large sense, i.e. the wastebasket (Pitz 2007). Indeed, in vain do we look for a semantically and formal coherent classification. In any case, the idea of "byname" in a larger sense does not indicate a motivational category.

In order to avoid the "wastebasket", I will propose a dichotomy, where the two categories, each, form a uniform group of motivations with further subdivisions. I will, as usual, account for the first etymology. The so-called suffixes, prepositions and articles are in fact fossilized.

I will adduce some English, Dutch, French and German examples.

Thus, in the classification of personal names, I propose a major division into relational and characterizing names. 
In the relational names, there is a relation between the name bearer and an entity outside of that person, for instance: a family or another entity outside of this person, a place, or time.

This concept of relation essentially applies to the meaning of the genitive, namely origin, human or geographical, where two entities are related; for instance: the name Robin-s, Robin-son, 'son of Robin' (Reaney 1979).

On the other hand, we have characterization, which refers to one and the same person, where some property of the name bearer is named, for instance: names such as Smith or Black.

First, I will deal with relational name-giving, subsequently with characterization.

\section{Relational name-giving}

In relational name-giving, the motivation can largely be captured by the different polysemous content of the genitive case, or the meanings of the preposition corresponding to of (Goossens 1999: 24-25; 2011). Here, the name bearer has a stable relation to another entity, a person or family, a place, or a point of time. It concerns a binary relation, in which the name bearer is linked to an external entity, for instance: the son or the daughter linked to the father. Thus, these binary relations are not characteristics of the name bearer as such.

\subsection{Names referring to a familial relation, such as "father - son" or "father - daughter", among others}

As a rule, family names referring to a familial relation belong to the well-known type "father - child", especially "father - son". Numerous are the names ending in -son, Robert-son, David-son, William-son, Richard-son. Less so, beginning with fitz- ('son'): Fitz-gerald, Fitz-robert. A genitive we find in William-s, Robert-s, and so on. In French: A-Georges 'son of Georges', AU-Jean 'son of Jean', A-LA-Marie 'daughter of Mary', hence a matronymic (Rateau, communication). In Dutch, we encounter, for example: Saereman(s) 'husband of Sarah.' Thus, we could speak of "human origin". In recent times, we encounter, in Dutch, the preposition van 'of, from', as in Van Geert '(son) of Gerald'.

\subsection{Toponymic names referring to topographical features, or even a house name}

In some cases, we encounter family names derived from names of cities: London, York, Washington, as a rule without prepositions; French Bergerac, or De-Lille ('from Lille'). Anglo-Norman used the ancient preposition de: de Barton, de Asseby, etc. Dutch often uses the preposition van in Van Leuven ('from Louvain'), Van Brussel ('from Brussels'). German does not use many prepositions: van/von Wien ('from Vienna') (Nübling and Dammel 2007: 148).

In another subclass, topographical names derived from a feature of the landscape are encountered. Some are based on houses, and the like. We find such topographical names as: Field, Ford, Heath, Lake, Bridge, Green, Mill, Pitt, Orchard etc. (McKinley 
1977: 42). In German (cf. Nübling and Dammel 2007), very frequent names are used in topographical contexts, for example: Busch ('forest'), Berger ('on the mountain'), Zumbach ('on the rill'), Von-dem-driesch ('from the meadow'). In Dutch and French, these family names are often construed with preposition, with or without definite article: $D u$-Camp ('from the field'), De-la-vigne ('from the vineyard'), Des-champs ('from the fields'). In Dutch, we encounter especially, for instance, Van-den-berg ('from the mountain'), Van-de-velde ('from the field'), and also without article: Van-dries.

Equally, we encounter house names: Dutch Kelder-man(s) ('from the cellar'), and French Du-château ('from the castle'), Du-moulin ('from the mill').

Foundlings (in the $18^{\text {th }}$ and $19^{\text {th }}$ century) were often found on the threshold of houses: Dutch In 't Portael ('in the porch'). Without any attestation we could never surmise that the name Temmerman ('carpenter') meant, in this case, 'found at the doorstep of citizen Temmerman'!

In French, we encounter prepositions plus article: $d u$ and $d e-l a-D u$-pont ('from the bridge'), De-la-rivière ('from the riverside'). It appears that French and neighboring West Flemish form a kind of "Sprachbund" (Pitz 2007: 222), sharing their prepositions plus article.

Finally, we encounter names related to time, especially with foundlings. A relation may originate between a baby and the month when it was found, for instance: Dutch Januari ('January'), November, Paeschen ('Easter'); German Freitag ('Friday'); French Lundi ('Monday'), Juin ('June'), Vendémiaire ('revolutionary month name'), and so on.

\section{Characterizing name-giving}

As I said before, the analysis of the two major categories of personal name-giving (namely: relational and characterizing) proves to be a significant distinction.

While the relational entities of this subclass point to the name giver as somebody who is related to another entity, person, place or time, in the second subclass, the person as such is characterized by one or another property or an activity, which is more often than not, metaphorical or metonymical.

We see a continuum of activities like professions to purely physical properties. It can be sketched as follows:

Professions $\rightarrow$ occupations $\rightarrow$ social status and behavior $\rightarrow$ personality features $\rightarrow$ psychological properties $\rightarrow$ special physical characteristics..

Usually, these are lasting or repeated features, which are positive or negative, of a metaphorical or metonymical nature. In historical contexts, the interpretation may cause difficulties. When somebody is called Stone, it can refer to a mason, but that is far from sure.

Let us start with the description of occupations, which show the greatest prestige, namely professions, which are numerous and are in probably all European countries the main motive for naming (Nübling and Dammel 2007: 144). But this "prestige" 
is often a mockery, in all languages. We find offices like Mayor, Guardian, Bishop, in French L'évêque, in Dutch De Meyer. Further, there are denominations for servicemen like drivers and clerks. Better known are the names that indicate handicrafts such as Fisher, Farmer, Shepherd, Taylor, Baker, Miller, Carter, Thatcher, Cook, Butcher, Smith, Mason, etc. Metonymic denominations of the type Stone, probably for a mason, or Meal for a miller probably show a lesser appreciation. At least, I know that it is like this in my dialect, for instance: Miel Gazet ('Emile newspaper') for a door-to-door vendor of newspapers, which is not a highly appreciated occupation.

In the Dutch-speaking and the French-speaking areas we encounter in the "Sprachbund" the fossilized definite article as the first syllable, such as Dutch De-smet ('the-smith') and French Le-fèvre ('the-smith'), but of course not the prepositions van and $d e$, which we found for such relational names of origin, as Dutch Van Leuven or French De-la-rivière. This situation is to be expected. It is a formal indication of the dichotomy sketched in this paper: relational (occasionally with preposition) and characterizing names (occasionally only with definite article).

We will now go on with our continuum of characterizing names. We encounter all kinds of occupations or activities like Robber, etc. Such names are often of a pejorative kind. This frequently applies to sentential names (so-called Satznamen in German), which are of a verbal nature, such as the famous name Shake-speare ('shake the spear'), Drink-water. But we also find these names in the whole of Western Europe, for instance in Dutch Breck-pot ('break' + 'pot'), in German Storte-becher ('shed' + 'cup'), in French Tu-chat ('kills' + 'cat'), Boi-leau ('drink the water').

An affiliated activity is shown by so-called delocutives, which point to the habit of the name bearer of using the same conspicuous word or expression. In family names, which go back to centuries ago, it is difficult to find these delocutives. Yet, favorite names are the Latin ones in an ecclesiastic context, such as Deogracias, Cristus, and Ergo.

Certain habits show a social behavior, a certain characteristic, or a psychological property. Surely, such names are, as a rule, pejorative (Nübling and Dammel 2007: 145), like the famous writer's name (Oscar) Wilde, Hauteyn (French 'haughty'), French Sauvage ('wild'), Dutch De-wilde ('the wild'). Metaphoric denominations are animal names like Hare, Ass, Sparrow. Sometimes, we observe positive characteristics in names such as Welikemt ('well combed'), Gay, Wise, Friend; Dutch De Vriend ('the friend'); French Le-bon (the good), also possessive pronouns as in Mon-ami ('my friend'). Rarely are found [preposition + article] like Dutch Met-de-penningen ('with the pennies', i.e. rich), but never van/von, which is the preposition of relational names.

Physical properties are encountered in Long, Short, Small, Black, Brown; French Lebeau ('the handsome'), Legros ('the fat'); Dutch De Langhe ('the long'), Decort ('the short'). These bodily characteristics are the most conspicuous ones. They are also the most static ones.

With these we have come to the end of the continuum of names, consisting of characteristics of the person himself or herself. 


\section{Conclusions}

The dichotomy of the diachronic structure of family names is founded on semantic and formal criteria.

Starting from the semantic motivation, we have observed, in the case of relational name-giving, a genitive-like relation between the name bearer and the entity, another person, place, or time.

In the case of characterizing name-giving, the name bearer is represented as the person who displays a striking characteristic of himself/herself, without another entity involved. This is not seldom metaphorical or metonymical.

But young people in Flemish schools (I got it from memoirs of my students) use nearly only characterizing denominations. They seldom use relational naming. They aim at physical, psychological and behavioral features, for instance, not seldom in English Jaws, the Queen, Bitch, Calamity Jane, and so on. Also, they like to play with word-forms and sounds. Relational name-giving does not interest them.

On the formal side, for the relational name-giving we have, in English, the genitive $-s$ and the affixes -son and fitz-for patronymics.

In toponymic names, we encounter in English almost no endings.

In contrast, we find in French $d u$ ('of the' - Du-château 'of the castle') and de-la ('of the'): De-la-rivière ('of the river'). Likewise, Dutch uses van-den in Van-den-berg ('of the mountain'), van-der in Van-der-bruggen ('of the bridge'), and so on. Rarely, more recent anthroponyms such as Van Geert ('of Gerald') are encountered.

In French and Dutch characterizing names, we find only the article, for instance: French Le-beau ('the handsome'), Dutch De-langhe ('the long'), and so on.

\section{References}

Brendler, Andrea and Silvio Brendler (eds.). 2007. Europäische Personennamen. Ein Handbuch von Abasisch bis Zentralladinisch. Anlässlich der 65. Geburtstage von Rosa Kohlheim und Volker Kohlheim. Hamburg: Baar.

Goossens, Jan. 1999. Motivierung bei Familiennamen (deren Müller einer ist). In Niederdeutsche Wörter. Festgabe für Gunter Müller zum 60. Geburtstag am 25. November 1999, R. Damme and H. Taubken (eds.), 21-33. Münster (Niederdeutsches Wort 39).

Goossens, Jan. 2011. Namenklassen und Spiegelung in der niederländischen Familiennamengeographie. In Familiennamengeographie: Ergebnisse und Perspektiven europäischer Forschung, Rita Heuser, Damaris Nübling and Mirjam Schmuck (eds.), 43-60. Berlin/New York: de Gruyter.

McKinley, Richard. 1977. The Surnames of Oxfordshire. Leopard's Head Press.

Nübling, Damaris and Antje Dammel. 2007. Das deutsche Personennamensystem. In: Brendler und Brendler, 139-152.

Pitz, Marina. 2007. Das französische Personennamensystem. In: Brendler and Brendler, 215-226.

Reaney, P.H. 1979. The Origin of English Surnames. London/Boston: Routledge and Keagan Paul.

Van Langendonck, Willy. 1996. Bynames. In Ein internationales Handbuch für Namenkunde, 
E. Eichler, G. Hilty, H. Löffler, H. Steger and L. Zgusta (eds.), 1228-1232. Berlin/New York: de Gruyter.

Van Langendonck, Willy. 1999. Merkmale der Personennamengebung durch flämische Jugendliche. In Akten des 18. Internationalen Kongresses für Namenforschung (Trier 1993), Band III: Namensoziologie, M. G. Arcamone and D. Kremer (eds.), 247-254. Tübingen: Niemeyer.

Van Langendonck, Willy. 2007. Theory and Typology of Proper Names. Berlin/New York: Mouton de Gruyter. 